\title{
Correction to: Impact of the Covid-19 pandemic on primary care utilization: evidence from Sweden using national register data
}

\author{
Björn Ekman ${ }^{1 *}$ (]) Eva Arvidsson ${ }^{2,3}$, Hans Thulesius ${ }^{1}$, Jens Wilkens ${ }^{1}$ and Olof Cronberg ${ }^{1}$
}

\section{Correction to: BMC Research Notes (2021) 14:424} https://doi.org/10.1186/s13104-021-05839-7

Following the publication of the original article [1], the authors informed us that a typographical error had occurred during the final stages of processing: the thousand comma-separators in Table 1 had inadvertently been misplaced.

The correct table is included in this Correction as well as the original article, which has already been updated.

Table 1 Primary care consultations by type and year, selected regions

\begin{tabular}{lll}
\hline Consultation type & Year & \\
\cline { 2 - 3 } & $\mathbf{2 0 1 9}$ & $\mathbf{2 0 2 0}$ \\
& $\mathbf{N}$ & $\mathbf{N}$ \\
& $\mathbf{\%}$ & $\mathbf{\%}$ \\
\hline Clinic visits & $10,499,364$ & $8,819,487$ \\
& 86.9 & 81.3 \\
Telemedicine contacts & 320,873 & 269,609 \\
Home visits & 2.7 & 2.5 \\
& 159,844 & 171,380 \\
Telephone/letter contacts & 1.3 & 1.6 \\
& $1,099,187$ & $1,587,442$ \\
Total & 9.1 & 14.6 \\
\hline
\end{tabular}

Source: VTDB 2019 and 2020

\author{
Author details \\ ${ }^{1}$ Department of Clinical Sciences, Malmö, Lund University, Jan Waldenströms \\ gata 35, 20205 Malmö, Sweden. ${ }^{2}$ Futurum, Region Jönköping's County, \\ Jönköping, Sweden. ${ }^{3}$ School of Health and Welfare, Jönköping University, \\ Jönköping, Sweden.
}

Published online: 22 February 2022

\section{Reference}

1. Ekman B, Arvidsson E, Thulesius H, Wilkens J, Cronberg O. Impact of the Covid-19 pandemic on primary care utilization: evidence from Sweden using national register data. BMC Res Notes. 2021;14:424. https://doi.org/ 10.1186/s13104-021-05839-7.

\section{Publisher's Note}

Springer Nature remains neutral with regard to jurisdictional claims in published maps and institutional affiliations.

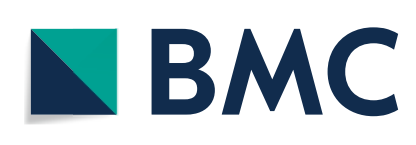

(c) The Author(s) 2022. Open Access This article is licensed under a Creative Commons Attribution 4.0 International License, which permits use, sharing, adaptation, distribution and reproduction in any medium or format, as long as you give appropriate credit to the original author(s) and the source, provide a link to the Creative Commons licence, and indicate if changes were made. The images or other third party material in this article are included in the article's Creative Commons licence, unless indicated otherwise in a credit line to the material. If material is not included in the article's Creative Commons licence and your intended use is not permitted by statutory regulation or exceeds the permitted use, you will need to obtain permission directly from the copyright holder. To view a copy of this licence, visit http://creativecommons.org/licenses/by/4.0/. The Creative Commons Public Domain Dedication waiver (http://creativecommons.org/publicdomain/zero/1.0/) applies to the data made available in this article, unless otherwise stated in a credit line to the data. 